Article

\title{
A Customized Decision Support System for Renewable Energy Application by Housing Association
}

\author{
Aleksandra Besser*(D), Jan K. Kazak ${ }^{\mathbb{D}}$, Małgorzata Świąder $\mathbb{D}$ and Szymon Szewrański $\mathbb{D}$ \\ Department of Spatial Economy, Faculty of Environmental Engineering and Geodesy, Wrocław University of \\ Environmental and Life Sciences, Grunwaldzka 55, 50-357 Wrocław, Poland \\ * Correspondence: aleksandra.besser7680@gmail.com
}

Received: 5 July 2019; Accepted: 7 August 2019; Published: 13 August 2019

check for updates

\begin{abstract}
One of the major problems in socio-environmental systems is the growing depletion of non-renewable resources and environmental degradation, resulting from inadequate environmental management and planning. Deepening environmental problems have forced countries to create management instruments that will help repair damage and support environmental protection efforts. The aim of this research is to develop a customized decision support system for the management of renewable energy based on the existing Geographic Information Systems (GIS). The proposed tool enables assessing the potential of solar energy production at the local scale, analyzing each rooftop. Due to the scale of the analyzed area and the details of the assessment, the tool is customized to the needs of housing associations. The system combines an existing GIS tool for calculating the solar radiation potential of rooftops (SOLIS) together with Tableau software that was used to aggregate and analyze data. In order to present the applicability of the developed tool, visualizations were prepared based on housing buildings managed by the "Biskupin" Housing Association in Wrocław (Poland) which is responsible for the management of 3415 residential premises. The created system based on spatial and environmental data will help to decide how to manage the available resources and the environment at the local scale while reducing the pressure on the environment. The tool allows for the aggregation, filtering and presentation of spatial data for the entire area of a housing association, as well as for a single building.
\end{abstract}

Keywords: decision support system; renewable energy; solar energy radiation; sustainable development; ArcGIS; Tableau

\section{Introduction}

As a result of the progress of civilization, structures of the natural system and various spheres of the Earth were transformed [1]. These transformations are the result of various activities and phenomena occurring in the social, economic and environmental sphere. The creation of new settlement units caused the increase in the population in a given area. Clusters of the population indirectly and directly use natural resources offered by the Earth to survive. As a consequence, the development of urban environments led to the depletion of non-renewable resources and even environmental degradation. Initially, it was exploited at a local scale until the 20th century, when the period of industrialization began. Increasing technological and scientific progress as well as civilization development resulted in increased work efficiency and increased environmental exploitation [2,3]. It was realized that the effects of human activities on the environment will not appear immediately, and their consequences will be felt by future generations [4].

From year to year, the demand for resources, i.e., energy [5], increases and this means that local authorities should look for alternative sources to ensure clean energy for their residents. In 
households, energy is most often used for heating rooms, water and cooking meals [6]. According to the energy consumption in households, the largest percentage of the population uses solid fuels, mainly hard coal and wood. The use of energy fuels is associated with the increased exploitation of non-renewable resources and, as a consequence, negative impacts on the air quality $[7,8]$. In order to reduce environmental pollution, many countries have decided to use renewable energy for energy purposes. One of the renewable energy sources with high potential is solar radiation, which is an inexhaustible resource. Solar energy systems are gaining popularity due to easy and universal access to the resource [9]. The use of solar technology such as photovoltaics using renewable sources in the urban environment will allow the use of clean energy, limiting the use of non-renewable sources such as coal for building heating [10].

Governments have introduced many programs [11], action plans [12,13] and documents at an international level $[14,15]$ to prevent further, uncontrolled depletion of the natural environment [16]. However, one of the most urgent problems is to create a system that will allow the use of environmental resources (including energy) in a sustainable manner, ensuring the existence and development of humanity [17]. Such a system would require a reduction in socio-environmental vulnerability in order to guarantee the stability of processes driven by humans in the built environment reality [18]. The system should rationally supervise the management of environmental resources in order to provide future generations with the opportunity to live in a quality environment similar to the one in which it currently resides [19]. In order to improve the resources, management novel tools using the possibilities of data sources and computation abilities should be implemented at the local level [20]. That refers also to the domain of solar energy. Many solutions for solar radiation assessment are predesigned for regional studies [21,22] and, therefore, do not suit the needs of local stakeholders. Advanced IT tools, including decision support systems, are becoming increasingly popular and are often used in environmental management, including in the area of renewable sources [23], air quality [24], water ecosystem [25] or impurities from agriculture [26].

The use of decision support tools results in making more rational and effective decisions [27]. By calculating indicators describing a given problem and analyzing its relationships, we can graphically see and understand how the phenomenon would change overtime, what impact it would have on further development and, as a result, make the conscious decision [28]. The system itself does not respond to the problem. It processes the entered data and the user, based on his expert knowledge, checks the correctness of the data, prepares information, interprets the results and makes a subjective assessment of the variants [29]. In addition, the model uses various data sources, e.g., thematic maps, satellite images or spreadsheets, which are adapted to the needs of a given issue and require different methods and algorithms of recreation [30]. Adopting appropriate multi-criteria assumptions in decision support systems and adapting data to the spatial dimension in GIS systems would allow for creating a system with an integrated approach to planning and managing environmental resources [31,32].

Despite the fact that decision support systems are well known in the literature, the complex and diverse issues that could use these tools do not allow developing one universal solution. In order to convince users to apply such systems, there is a need to customize solutions according to the needs of users [32]. The technical support of local stakeholders in renewable energy implementation might also be helpful to combat an emerging problem of energy poverty [33] that decreases the quality of life of inhabitants in urban areas [34]. The issue of energy poverty is especially important in the context of ageing populations [28] despite the fact that long-term care expenses are constantly growing in Poland [35]. Urban renewal actions, also in the context of improving energy performance, will increase the value of properties [36-39], which would enable housing associations to achieve customer satisfaction by showing the costs together with benefits of these investments $[40,41]$. Therefore, there is a need to develop a flexible approach, matching the tool to the available data as well as the key drivers of the management process [31].

Therefore, the aim of this research is to develop a customized decision support system for renewable energy application based on the existing Geographic Information Systems (GIS). The system 
combines an existing GIS tool for calculating the solar radiation potential of rooftops (SOLIS) together with a business intelligence system (Tableau). The integration of these two computing environments enables enlarging the functionality of the developed solution [42]. The created system contains data, which can help managers to decide how to manage reducing energy consumption at the local level and the pressure on the environment. The decision support system allows aggregation, filtering and presentations along with the assessment of environmental data. As a customized solution has to be developed according to the needs of the user, the tool was designed based on the needs of one Polish housing association. The presentation of the applicability of the developed tool is shown in the case of housing buildings managed by the "Biskupin" Housing Association in Wrocław (Poland). The assumed impact of the developed tool application is to activate a housing community to reduce the consumption of electricity and heat through the use of modern solutions based on renewable energy sources, which will help to reduce the consumption of non-renewable resources. The model for the management of renewable energy is built in two parts-the first part, which contains analyses in a modified GIS model, and the analytical part, which includes the analysis of the obtained results of tests performed in the Tableau software (version 2018.3). In the first part, solar radiation was calculated in a particular month in 2018 in the ArcGIS program (version 10.5.1.) with the help of the Solar Area Radiation tool (SOLIS).

The direction of changes in the energy sector in Poland is not a new issue. Policies and action promoting renewables were undertaken and implemented by Poland before joining the European Union in 2004 [43]. However, the share of renewable energy is still relatively low. The target defined in the project entitled Energy Policy of Poland until 2040 aims to increase the share of renewable energy sources up to $21 \%$ in the whole energy sector in 2030. Achieving that goal requires doubling this source in one decade [44]. Therefore, a proposed model for energy resources management could also be relevant in this context.

\section{Methodology of Environmental Management Decision Support Tool}

The decision support system that has been created combines the functionality of the GIS program and Business Intelligence systems (BI), the combinability of which allows for better user functionality (Figure 1).

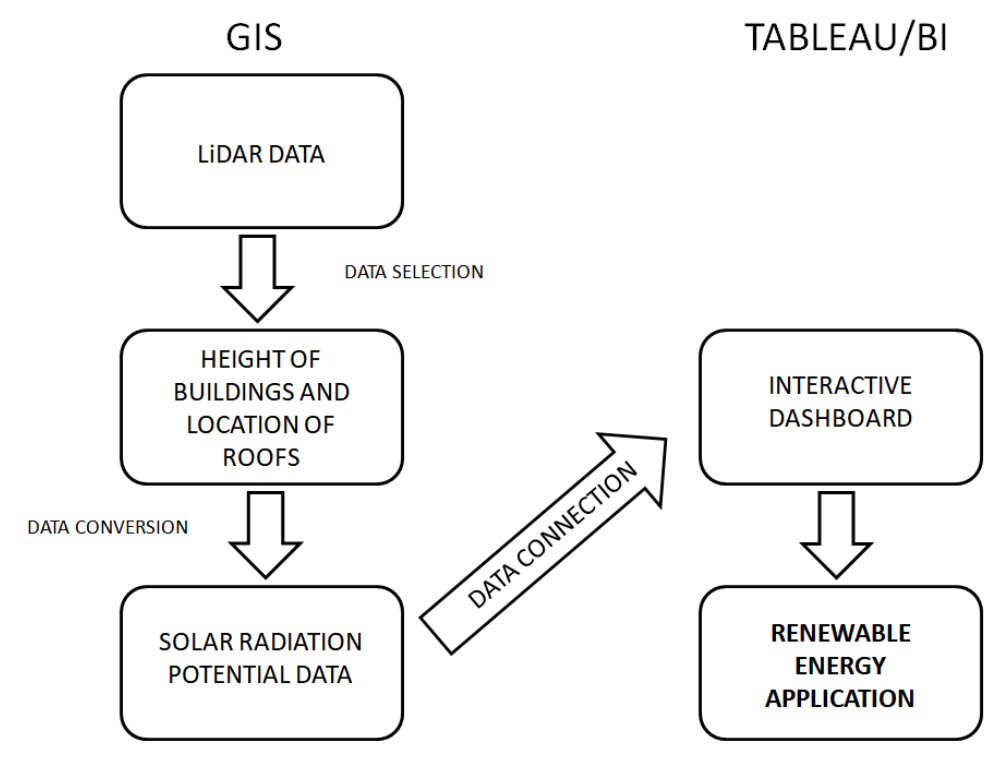

Figure 1. Framework of operation diagram. Source: Own elaboration.

The input data were represented by a Light Detection and Ranging (LiDAR) dataset, which was a base for the extraction of buildings together with height information. The input data were a basis for 
solar radiation calculations, and then connection with the BI tool. The use of spatial data in Tableau software allowed for interactive dashboard building. The result of this connection and dashboard building was a detailed model for renewable energy application.

\subsection{Research Area}

The test object in this work is the "Biskupin" Housing Associationin Wrocław (Poland), which has been operating since 1959. The properties included in the development area are located in the north-eastern part of Wrocław, in the Lower Silesia Voivodship.

The cooperative consists of 120 properties, including housing (58) located in the following districts: Ołbin (11), Biskupin-Sepolno-Dabie-Bartoszowice (46), Grunwaldzki Square (2), and Nadodrze (3). The buildings located inOłbin and Grunwaldzki Square come from the pre-war period. Most real estate are located in Biskupin-Sepolno-Dabie-Bartoszowice and were created in the period 1919-1935. They are mainly multi-family two-story terraced houses, as well as 4-or 6-storey detached houses. The buildings located in Gersona 5 and Olszewskiego 149-153 street are dated from the period 2010-2015 and they include multi-family buildings. The property on the Biskupin estate also includes buildings constructed of large, prefabricated concrete slabs, which were built in the 1960sand 1970s. The housing estate in Nadodrze dates back to the 19/20th century and has a quarterly development layout. The buildings were not so damaged during the war. In Nadodrze, the buildings are mainly high tenements and cobbled streets, whereas the housing development in Plac Grunwaldzki is from the pre-war period.

The height of the buildings depends on the location of the property and looks as follows:

- Biskupin-Sẹpolno-Bartoszowice-Dąie district: medium-sized, 4-7-storey buildings predominate, with the height of buildings between 10 main A. Mickiewicza street, through 16meters in the area ofGerson and S.Sempołowska Streets, and $22 \mathrm{~m}$ in the vicinity of Canaletto Street;

- Otbin district:average buildings dominate, 5 storeys with the height of buildings between $16 \mathrm{~m}$ along the streets of E.Stein and B.Prusa, and $22 \mathrm{~m}$ along the Daszyńskiego and National Unity (org. Jedności Narodowej) Streets;

- Grunwaldzki Square (org. Plac Grunwaldzki) district: 8-10-storey buildings, 20-22 m height;

- Nadodrze district: 8-10-storey buildings with a height of 20-22 m.

In the case of service buildings and garages, the maximum area of individual real estate varies between 3 and $6 \mathrm{~m}$ of a single-storey buildings. In addition, the co-operative also includes an accompanying infrastructure, such as waste containers, garages and service premises (62) (Figure 2). The analyzed area consists of 3415 residential premises, which are inhabited by approximately 6050 people. The area subject to the cooperative has in its resources in over $266,328 \mathrm{~m}^{2}$ of land.

\subsection{Model Framework}

In order to create an environmental management model in relation to solar energy management, this work relied on the existing decision support tool to assess the solar potential-SOLIS, which is available online in the form of the ArcGIS tool [45]. The SOLIS was made in the ArcGIS program with the help of the visual model Builder geoprocessing editor. Available instruments that can be used to create a model can be found in the ArcToolbox catalog in Spatial Analyst. The basic tool in the model is Area Solar Radiation. The SOLIS model is based on a set of multipart patches in the form of $3 \mathrm{D}$ building data (so-called multipatch), which is characterized by a $\mathrm{Z}$ value, showing the height of each patch-the minimum height and the maximum height. In this work, this tool has been modified. Obligatory input data that should be included in the model are the height value and roof area. In the model for the "Biskupin" Housing Association, instead of multipatch data, numerical digital data were used in the form of a point cloud in the LAS format from aerial laser scanning (LAS stands for LiDAR data exchange file), from which information on the minimum and maximum height of individual buildings and roof surfaces with inclination were obtained. The proposed modification enlarges the group of potential users, as in many cases multipatch data as a postprocessing effect might be not 
available, while LiDAR as raw data might be possible to obtain. Besides the data format, the model has changed the order of attribute selection - the roof surface is suitable for the installation of photovoltaic panels. In the primary formula (Figure 3a), the selection of cells presenting the value of radiation, with an area larger than $2 \mathrm{~m}^{2}$, takes place before the calculation of the solar potential, while in the second model (Figure $3 b$ ), the selection of such areas with an area larger than or equal to $2 \mathrm{~m}^{2}$ is the last element of calculation.
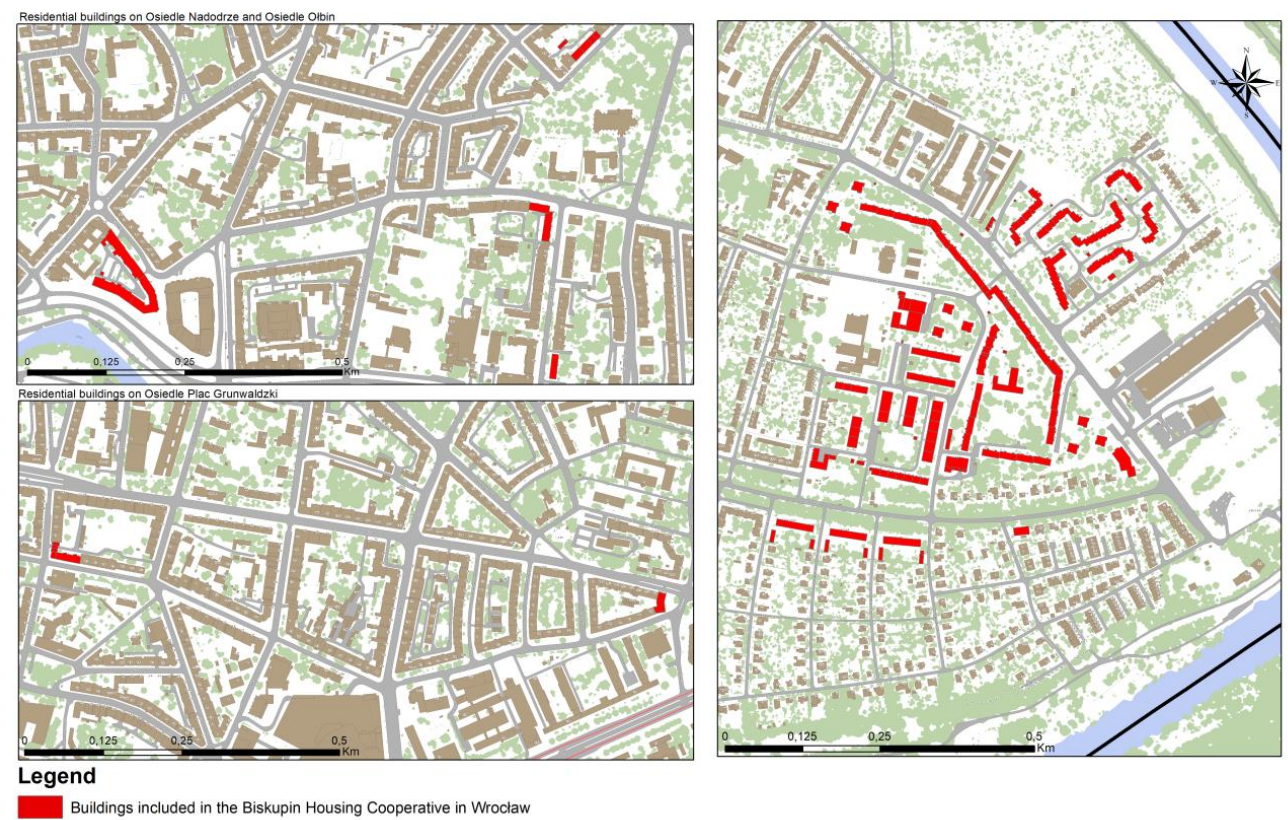

Figure 2. Buildings included in the "Biskupin" Housing Association in Wrocław in particular settlements. Source: Own elaboration using ArcGIS.

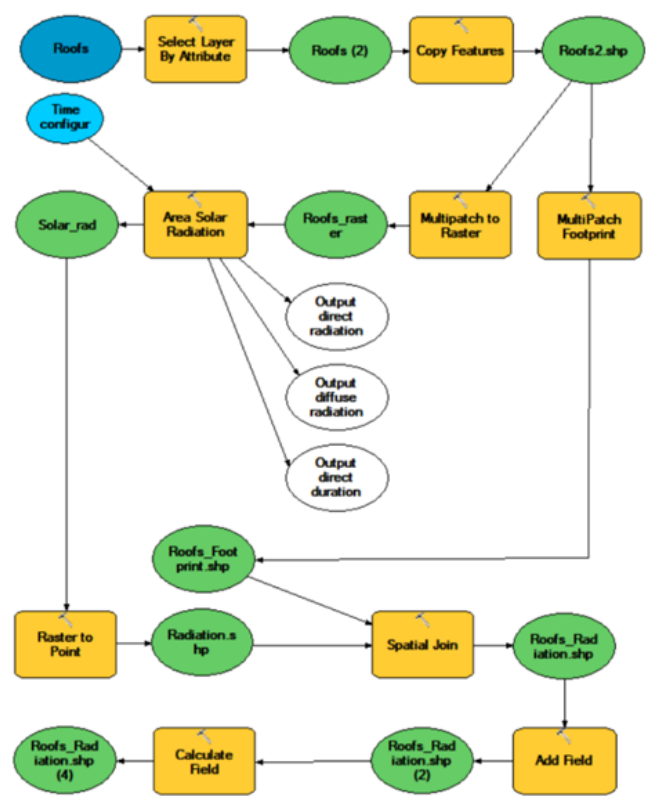

(a)

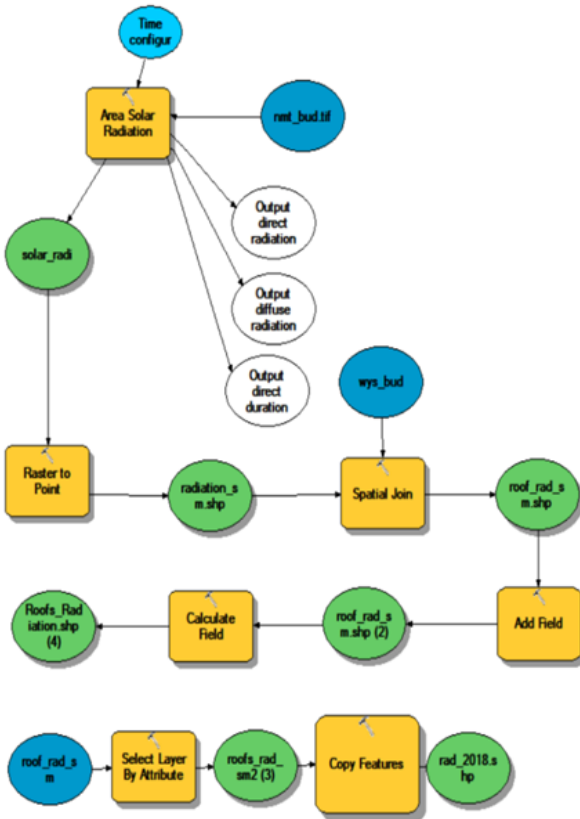

(b)

Figure 3. Workflow of model calculation: (a) presents the solar radiation potential of rooftops (SOLIS) calculation workflow; (b) presents the modified model calculation workflow. Own elaboration using ArcGIS. 


\subsection{Conversion of Data}

The first stage of the work in the model was the development of data that will be the basis for calculating the amount of potential solar radiation with the division into individual months in 2018. Numerical altitude digital data were used for the analysis, which contains a point cloud from LiDAR (Figure 4). The following figure shows the digital spatial data in LAS format imported into ArcGIS. This data source was selected due to the fact that laser scanning technologies are being developed right now and already support a variety of domains with high-quality spatial data [46-48].

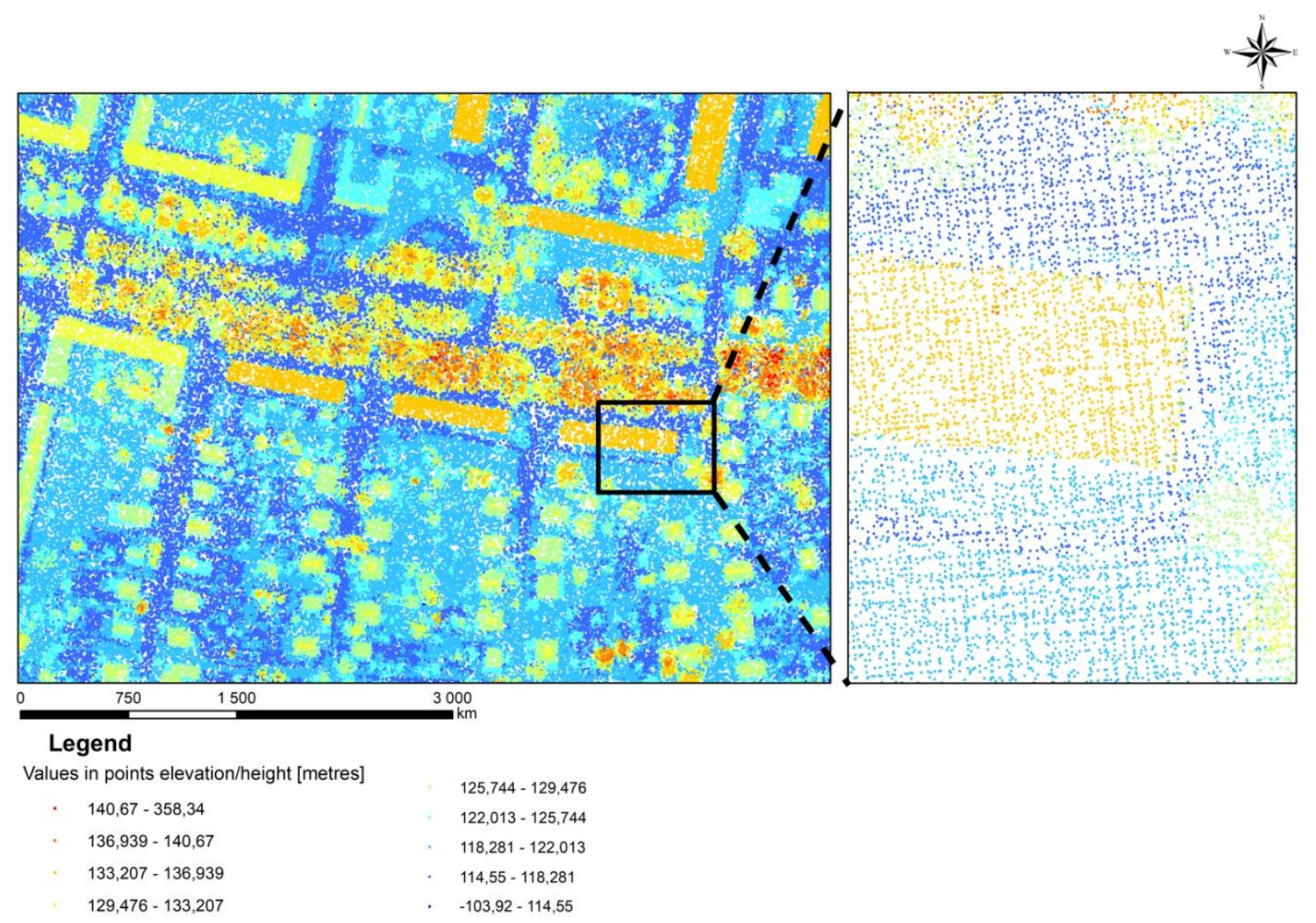

Figure 4. Input LiDAR data. Source: Own elaboration using ArcGIS.

In the analyzed area, urban development, the average density of points is 12 points $/ \mathrm{m}^{2}$. The data are available in LAS format and divided into the eight classes [49]. In order to obtain information about the minimum and maximum height of individual buildings from the LAS layer, it was necessary to select the data class named "6 BUILDING", which only shows buildings. The data conversion allows obtaining the altitude of the buildings, on the basis of which we can obtain data for the model.

\section{Results}

As a result of the analyses created in the model, vector layers were obtained with the value of average solar radiation per square meter of roof, as well as total radiation on the entire roof surface. Depending on the type, height, slope and exposure of individual roof fragments, the results of the analyses are different.

\subsection{Solar Radiation}

The obtained results did not take into account the actual weather conditions that appeared in 2018 and other objects that could obscure sunlight, like trees, and which affect the amount of actual solar radiation. Despite this, the results obtained constitute the basic information for the housing cooperative, with the possible value of the solar potential of the annual roofs of individual properties. 
On this basis, it will be possible to find roofs with the highest potential, which will allow the decision to install photovoltaic panels that will achieve the highest possible energy efficiency. This will allow the housing cooperative to reduce the consumption of non-renewable resources such as coal or gas and to reduce the emission of pollutants from the boiler room, and instead allow the use of clean energy sources. The most numerous groups are residential buildings, where the average roof potential of which is estimated between $613,777 \mathrm{Wh} / \mathrm{m}^{2}$ and $742,645 \mathrm{Wh} / \mathrm{m}^{2}-108$ roof patches (group IV) (Figure 5).

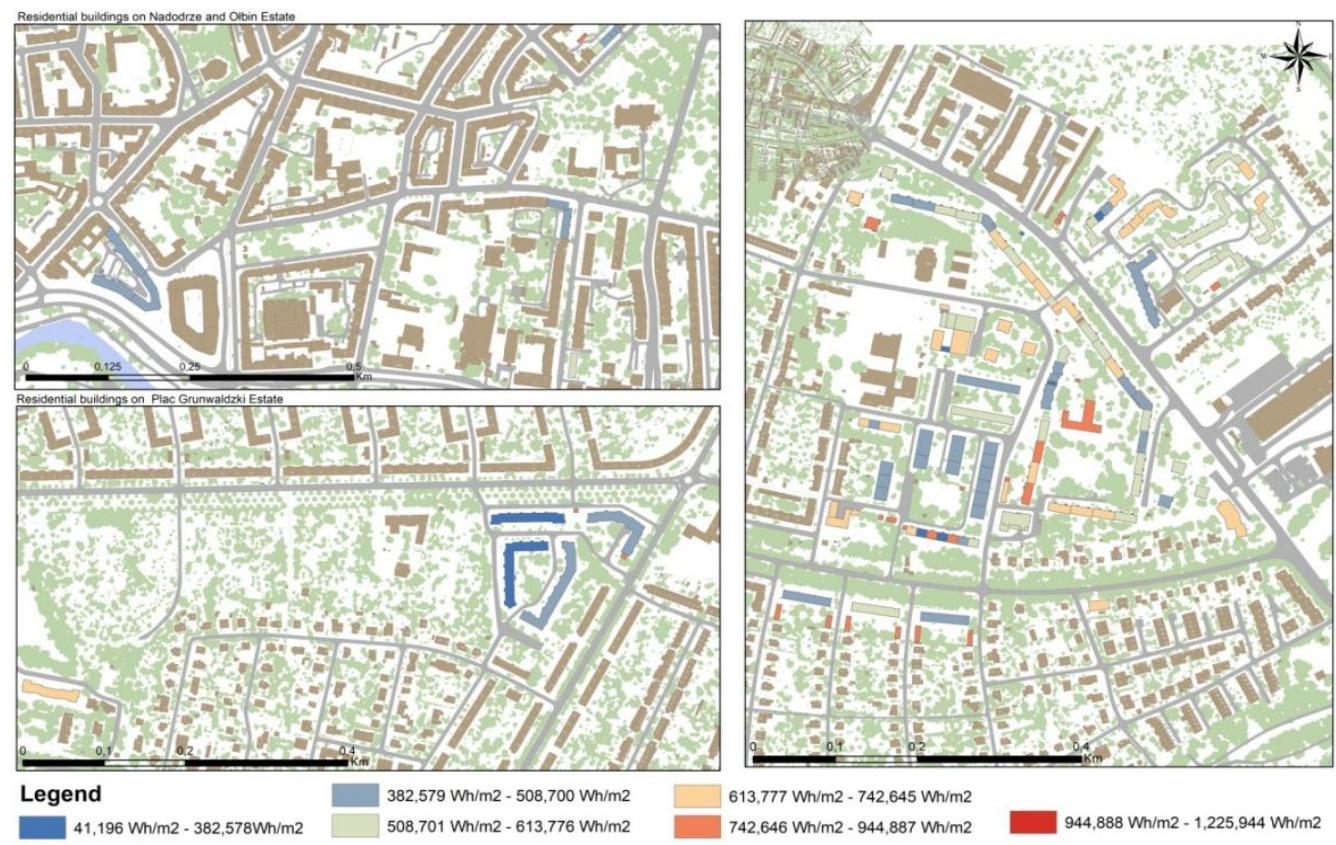

Figure 5. Solar potential per $1 \mathrm{~m}^{2}$ of roof properties included in the "Biskupin" Housing Cooperative in Wroclaw. The values of solar radiation are shownusing a blue-red color palette. The dark blue represents buildings with the lowest value of solar potential, the dark red represents the highest values of solar potential. Source: Own elaboration using ArcGIS.

The total roof area in this category is $19,721.36$ (23.33\% of the total area of all roofs). The second most numerous group is roofs with annual solar potential in the range of $382,579 \mathrm{Wh} / \mathrm{m}^{2}-508,700$ $\mathrm{Wh} / \mathrm{m}^{2}-103$ objects (group II) - the area of which is $18,808.41 \mathrm{~m}^{2}(22,25 \%$ of the surface of all roofs) Values of solar radiation potential at a similar level are also in the range $742,646 \mathrm{Wh} / \mathrm{m}^{2}-944,887 \mathrm{Wh} / \mathrm{m}^{2}$ (group V) - the area of which is $19,171.90 \mathrm{~m}^{2}$ At least for the large group, they constitute roof patches, and the amount of solar energy falling on their surface is $944,888 \mathrm{Wh} / \mathrm{m}^{2}-1,225,944 \mathrm{Wh} / \mathrm{m}^{2}$ (group VI) and $41,196 \mathrm{Wh} / \mathrm{m}^{2}-382,578 \mathrm{Wh} / \mathrm{m}^{2}$ (group I) during the year. The solar potential values can be different in neighboring buildings because, when calculating solar intensity, parameters such as the height of buildings, aspect, slope of roofs, size of roofs, number of roofs' patchesare taken into account. The values of individual parameters can give the total value of the solar potential other than in the neighboring building, which affects the final result of the intensity of solar radiation.

\subsection{Model of Environmental Ecision Support Tool}

Based on the obtained data, an interactive model of environmental management for the housing association was created in the Tableau program. The model includes a decision support tool for assessing the solar potential. This program is used to visualize the obtained data graphically and is easier to interpret. With the help of the tool, it will be possible to select the appropriate location of the solar installation by comparing the solar potential of individual buildings (Figure 6). 

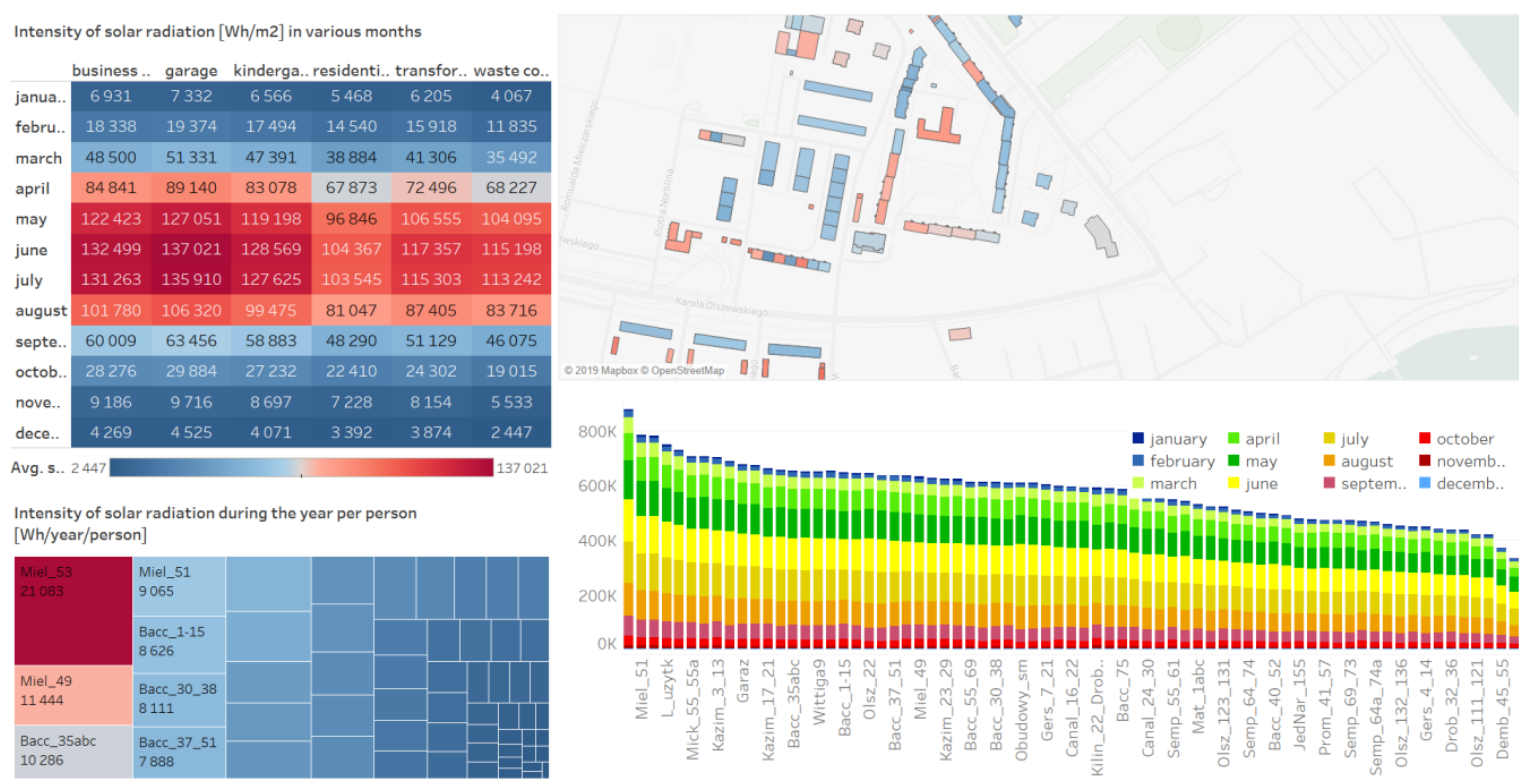

(a)
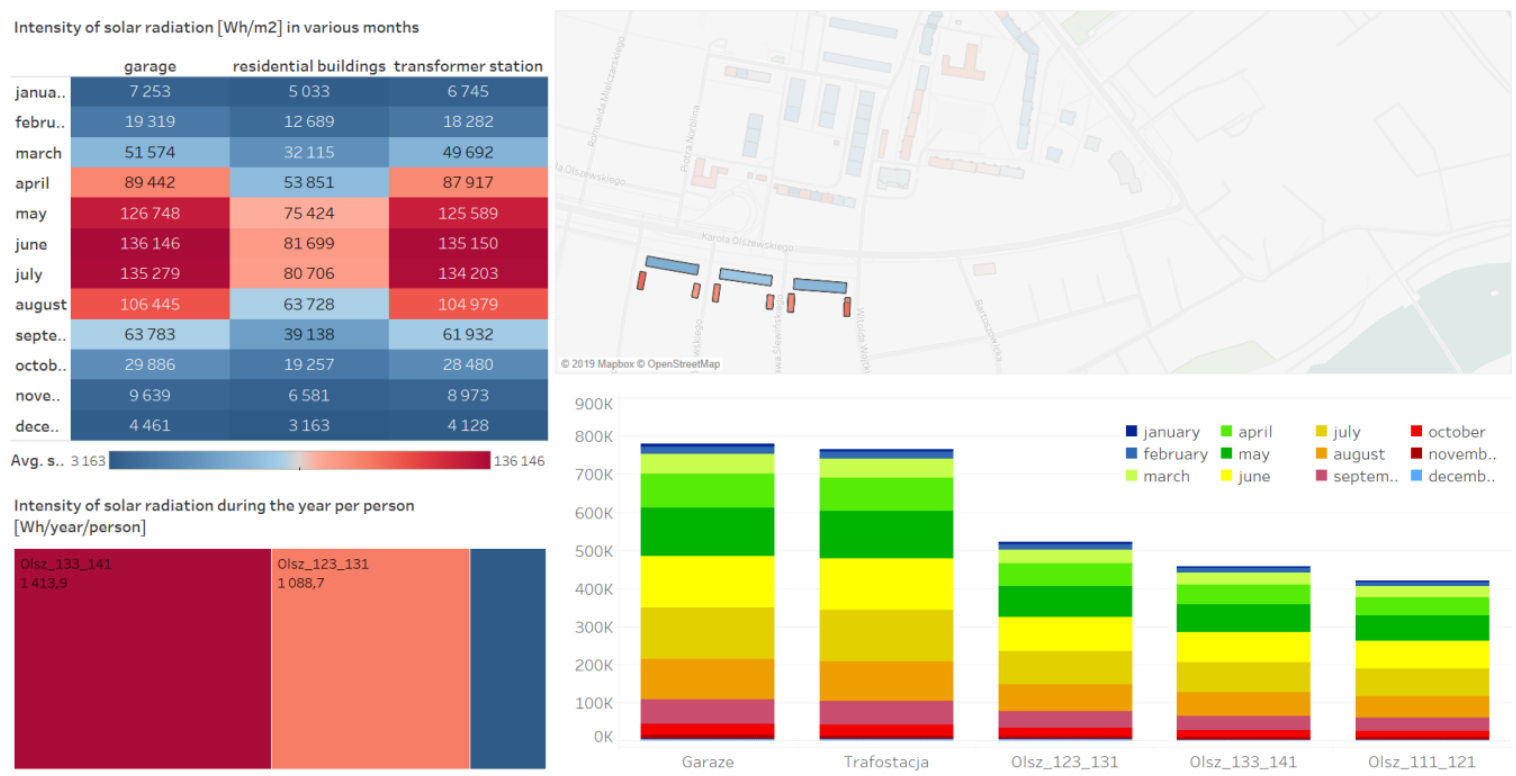

(b)

Figure 6. The customized interactive dashboard for renewable energy assessment: (a) General view; (b) selected buildings.Source: own elaboration using Tableau Software.

Using this model, the housing association is able to analyze the solar potential of individual properties during the year, and on their basis, decide on the introduction of a solar installation on roofs, the use of which would help reduce the consumption of electricity and heat. Demand for energy continues to grow year by year, which is why alternative sources are needed to manage the environment, which will help reduce excessive consumption of energy resources.

The model consists of three analyses and a map. The input data to the program were data in the form of a vector layer covering solar roof intensity values divided into months obtained in the ArcGIS 
program. The model is interactive, and, at the same time, it presents information on the sum of the total solar radiation intensity per year, per capita and solar potential depending on the type of real estate selected, group of real estate and a specific type of real estate. The model presents analyses regarding:

(1) The monthly solar potential for given types of buildings belonging to a housing association

The largest average solar potential in terms of the size of the building is garages and commercial premises. However, all properties have solar potential at a similar level. The total solar intensity in the month with the highest potential in June is for garages $137,021 \mathrm{Wh} / \mathrm{m}^{2}$. In almost every type of property, the period of the highest potential of solar radiation occurs from April to September (Figure 7).

\begin{tabular}{|c|c|c|c|c|c|c|c|}
\hline & business premises & garage & kindergarten & residential buildin. & transformer station & waste container & Avg. solar ra.. \\
\hline janua.. & 6931 & 7332 & 6566 & 5468 & 6205 & 4067 & $2447 \quad 137021$ \\
\hline febru.. & 18338 & 19374 & 17494 & 14540 & 15918 & 11835 & \\
\hline march & 48500 & 51331 & 47391 & 38884 & 41306 & 35492 & \\
\hline april & 84841 & 89140 & 83078 & 67873 & 72496 & 68227 & \\
\hline may & 122423 & 127051 & 119198 & 96846 & 106555 & 104095 & \\
\hline june & 132499 & 137021 & 128569 & 104367 & 117357 & 115198 & \\
\hline july & 131263 & 135910 & 127625 & 103545 & 115303 & 113242 & \\
\hline august & 101780 & 106320 & 99475 & 81047 & 87405 & 83716 & \\
\hline septe.. & 60009 & 63456 & 58883 & 48290 & 51129 & 46075 & \\
\hline octob.. & 28276 & 29884 & 27232 & 22410 & 24302 & 19015 & \\
\hline nove.. & 9186 & 9716 & 8697 & 7228 & 8154 & 5533 & \\
\hline dece.. & 4269 & 4525 & 4071 & 3392 & 3874 & 2447 & \\
\hline
\end{tabular}

Figure 7. Intensity of solar radiation $\left[\mathrm{Wh} / \mathrm{m}^{2}\right]$ in various months. Source: own elaboration using Tableau Software.

The average intensity of solar radiation in residential buildings is smaller than in business premises. This is due, among other factors, to the fact that residential buildings have different roof slopes, and the business premises included in the cooperative have flat roofs on which the position of photovoltaic panels will allow for higher solar energy accumulation. In addition, the roofs of residential buildings are more divided into parts in relation to business premises. However, residential buildings are higher than business premises.Therefore, the differences in the solar potential are close to each other. In relation to other objects, residential buildings have the lowest average intensity of solar radiation in the most sunny period (May-August). The highest average solar potential is provided by garages, the value of which is higher by over $30,000 \mathrm{Wh} / \mathrm{m}^{2}$ from residential buildings. Also, the kindergarten building as well the business premises havea higher solar potential per $1 \mathrm{~m}^{2}$ of roof. If photovoltaic panels are installed on the roofs of garages and waste containers, it will be possible to accumulate energy in the event of insufficient energy for nearby residential buildings.

(2) The annual solar radiation on all properties in the household association

The proposed model allows for verification of the solar potential for each building belonging to a housing association. The building located in Mielnickiego 13 street has the highest average potential of solar radiation-21,053kWh per year-which is three times the average energy consumption per person per year. Statistically, in Poland, a person consumes approximately $6111 \mathrm{kWh} /$ year [50]. A total of 28 buildings have a lower potential per inhabitant than the statistical amount of energy consumption per capita and, in 29 cases, solar panels will be able to produce an amount of energy that satisfies the needs of residents (Figure 8). 


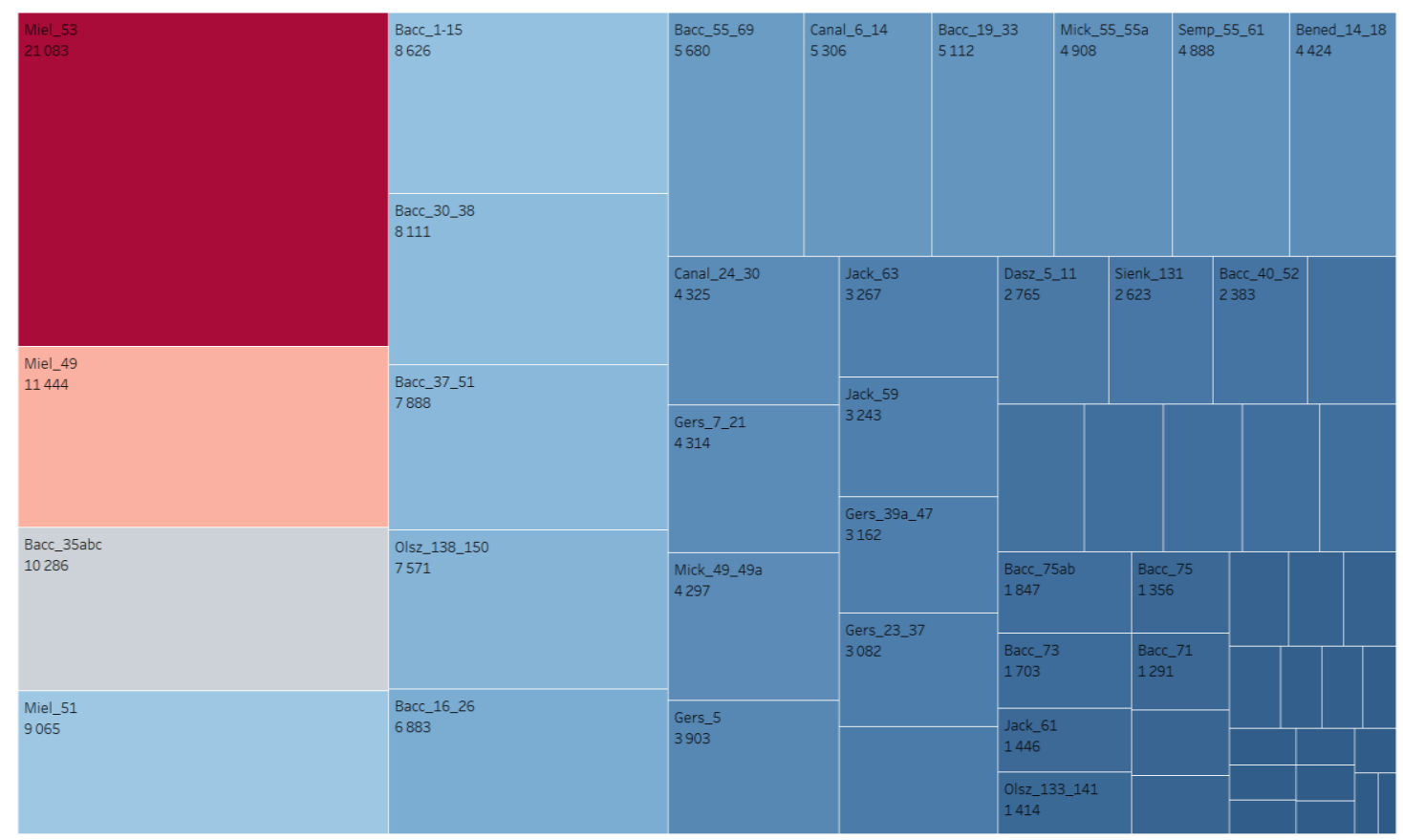

Figure 8. Intensity of solar radiation during the year per person [Wh/year/person]. Source: Own elaboration using Tableau software.

(3) The detailed annual intensity of solar radiation on all properties in the household association The model allows for the detailed analysis of the annual intensity of solar radiation. Therefore, itis possible to verify the annual value of solar radiation per given property, as well as the verification of solar potential during each month. The graph below presents the values of solar intensity per $1 \mathrm{~m}^{2}$ of real estate. The biggest potential in the year is the building located at Canallette 6-14 street, approx. $900,000 \mathrm{Wh} / \mathrm{m}^{2}$, which is a value higher than the average potential of solar radiation intensity in the whole of Wrocław $-828,924.8 \mathrm{Wh} / \mathrm{m}^{2}$. The smallest potential was recorded on the roofs of real estates located in Gersona 4-14 street and Olszewskiego 132-136-approximately 400,000 Wh/m² (Figure 9). The highest annual solar potential is located in the building at Canalette 6-14. This is due to the fact that the building is high, has 5 storeys, with a total height of $12 \mathrm{~m}$. In addition, the roof of the property is flat, which allows for higher possibilities of accumulating solar energy. In the months with the highest intensity of solar intensity, the potential ranges from 80,000 to $100,000 \mathrm{Wh} / \mathrm{m}^{2}$ of roof. The lowest solar potential occurs in January, November and December and its maximum value is up to $10,000 \mathrm{Wh} / \mathrm{m}^{2}$. However, the building with the lowest solar intensity is the property located at Gerson 4-14. The maximum intensity in months with the highest solar radiation is approximately60,000-80,000 $\mathrm{Wh} / \mathrm{m}^{2}$. The roof of the property is more divided (due to existing chimneys), which affects the total value of solar intensity. The largest share of energy possible to accumulate is in the period from May to September. The difference in the amount of intensity in some months is even several times higher. An example of this is the value of solar radiation intensity in real estate with the highest potential. In January, the intensity value is $8313 \mathrm{Wh} / \mathrm{m}^{2}$ and in June as much as $153,338 \mathrm{Wh} / \mathrm{m}^{2}$.

\subsection{Accumulated Energy vs. Energy Use}

Taking into account the obtained results, the integration of SOLIS and Tableau would allow for more detailed analysis, i.e., verification of accumulated energy during year versus actual annual consumption of energy by inhabitants of given residential building (Table 1). 


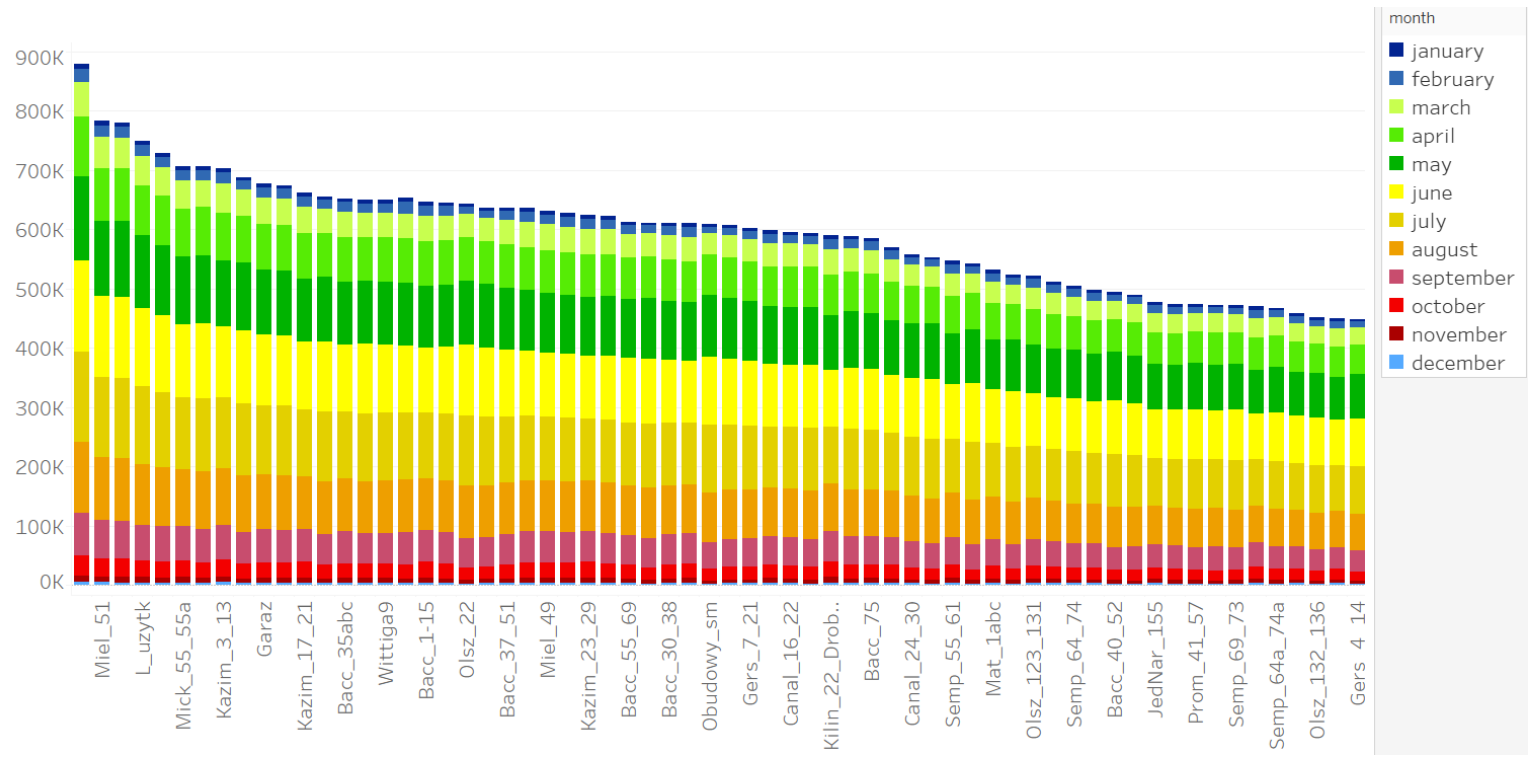

Figure 9. The intensity of solar radiation in particular months divided into the location of the property. Source: own elaboration using Tableau software.

Table 1. The comparison of accumulated energy to energy demand-examples from building inventory.

\begin{tabular}{|c|c|c|c|}
\hline Real Estate Code & $\begin{array}{c}\text { Annual Accumulated } \\
\text { Energy in Wh }\end{array}$ & $\begin{array}{l}\text { Annual Use of Energy } \\
\text { in Wh }\end{array}$ & Balance in Wh \\
\hline Olsz_111_121 & $271,141,195$ & $51,332,400$ & $+219,808,000$ \\
\hline Olsz_123_131 & $688,801,124$ & $48,888,000$ & $+639,913,000$ \\
\hline Olsz_132_136 & $705,721,916$ & $71,498,700$ & $+634,223,000$ \\
\hline Olsz_133_141 & $949,865,835$ & $49,499,100$ & $+900,366,000$ \\
\hline Olsz_138_150 & $715,400,977$ & $76,998,600$ & $+638,402,000$ \\
\hline Prom_25_39 & $523,210,936$ & $78,220,800$ & $+444,990,000$ \\
\hline Prom_41_57 & $803,637,760$ & $98,998,200$ & $+704,639,000$ \\
\hline Semp_55_61 & $624,099,638$ & $34,221,600$ & $+589,878,000$ \\
\hline Semp_63_67 & $501,570,235$ & $69,054,300$ & $+432,515,000$ \\
\hline Semp_64_74 & $404,252,992$ & $68,443,200$ & $+335,809,000$ \\
\hline Semp_64a_74a & $391,366,621$ & $62,332,200$ & $+329,034,000$ \\
\hline Semp_69_73 & $392,539,126$ & $81,887,400$ & $+310,651,000$ \\
\hline Gers_23_37 & $952,738,626$ & $99,609,300$ & $+853,129,000$ \\
\hline Gers_39a_47 & $970,299,234$ & $95,942,700$ & $+874,356,000$ \\
\hline Gers_4_14 & $745,840,280$ & $70,276,500$ & $+675,563,000$ \\
\hline Gers_5 & $844,439,276$ & $16,1330,400$ & $+683,108,000$ \\
\hline Gers_7_21 & $773,564,185$ & $42,777,000$ & $+730,787,000$ \\
\hline Jack_59 & $294,365,394$ & $19,555,200$ & $+274,810,000$ \\
\hline Jack_61 & $151,276,653$ & $21,388,500$ & $+129,888,000$ \\
\hline Jack_63 & $294,365,754$ & $19,555,200$ & $+274,810,000$ \\
\hline
\end{tabular}

When comparing the data obtained, it can be seen that each of the buildings has a higher solar potential than the current demand of residents for energy. By installing panels, the cooperative is able to produce almost $80 \%$ more energy than current demand. 


\section{Discussion}

The solar radiation tool developed in this study supports the process of improving energy performance by selecting these locations which present the highest potential for energy production at the scale of individual buildings. By converting the values in the model, information was obtained on the potential of each type of building, which vary due to their technical parameters and the surrounding objects. Such a solution is not possible in every solar radiation tool.

The tool developed by Hofierka and Kanuk presents an example of how GIS-based approaches effectively calculate the solar radiation for analyzed neighborhood. However, it does not allow selecting a single object or group of objects to compare with deleting other objects from analysis [51]. Moreover, due to the development of remote sensing technologies [52,53], a wider spectrum of data should be possible to use in solar radiation assessments. Kaynak et al. recently developed their software which accepts only CityGML-based file formats as input data. However, they highlighted that the direction of future works is to enlarge the type of data format types that can be used [54]. The modification that we did in this research modify an existing tool (SOLIS) exactly in that aspect, by using LiDAR as an input data source. However, LiDAR data processing is not a simple task. Processing the point cloud, the user should obtain aneasy and ready-to-use database, but most often the data are considered in terms of the position and elevation of buildings as well as intensity when applied $[55,56]$. In addition, the currently available resolution of LiDAR data limits the definition of roofs, which means that roofs, chimneys, dormers, antennas are not taken into account in the analyses, the use of which would help to more accurately determine the area available on building facades $[57,58]$. The other crucial aspect is functionality from the point of view of the user. Wijeratne et al. in their work "Design and development of distributed solar PV systems: Do the current tools work?" analyzed 23 software and four smart phone/tablet applications according to their features. Only two solutions were categorized as user-friendly [59].

In the case of our tool, by incorporating business intelligence environment, it was possible to integrate visualization on the map together with charts. The panels that were used in the interactive dashboard were selected based on the suggestions by specialists from housing associations. The tools allow selecting any object (or group of objects) on any panel and highlight the assigned value on other panels on the dashboard. That allows quicker and user-friendly visual analyses which meet the needs of non-professionals in GIS, who are responsible for environmental management at the level of housing association. Finally, the success of the application is connected with the affordability of the tool. The review of over 200 solar design tools shows that only 12 solutions give the possibility of dynamic visualization (similar like the tool developed in our study) and only four of them are freeware [60]. That shows the limitation in the promotion of developed tools in practice. In the case of our dashboard, it has to be designed in a pay-ware version of Tableau software. However, the use of the dashboard can be supported for free by Tableau Public. The proposed solution shows the solar potential at the scale of individual buildings. It also allows for verification if the produced energy could support the energy needs of inhabitants in a given area. However, the crucial element in energy management is the ability to control the issue of energy peaks. Such elements can be incorporated into decision support systems [61]. Therefore, future works should also focus on that aspect. Moreover, the approach does not include other elements in the area, such as trees. Therefore, the assessment could be incomplete and a lack of this data could represent a further limitation and necessity for the development of the model. The renewable energy applications by housing associations could also be relevant in other research, as in the context of energy poverty, vulnerable groups to energy poverty (impoverished people or ageing society) [28,62], spatial management [36], and comprehensive environmental management system $[63,64]$.

\section{Conclusions}

The developed customized decision support system for renewable energy application presented in the results proves that the aim of the study was fulfilled. Based on the obtained data, an environmental 
management model was created to assess the solar potential of roofs. The system combines an existing GIS tool for calculating the solar radiation potential of rooftops (SOLIS) together with a business intelligence system (Tableau). An interactive tool allows for the aggregation, filtering and presentation of data on the amount of solar intensity of each type of building in individual months, during the year and per capita. The environmental management model contains analyses in a modified model, and the analysis of the obtained results of tests. The tools used in this system result in making more rational and effective decisions. Thanks to the Tableau program, the property manager obtains information in an easy and transparent way. The created system of decision support contains data based on which it will be possible to reduce energy consumption and pressure on the environment at the local level using modern solutions in the energy sector. This tool was developed based on the cooperation between academics and practitioners from the housing association. Such an approach allowed including the information in interactive dashboards based on the needs reported by specialists in the environmental management domain.

The results obtained for the "Biskupin" Housing Association show that over 50\% of the analyzed rooftops has sufficient potential for solar radiation intensity per capita, and a smaller part of the property would provide half of the energy demand. The use of photovoltaic installation will allow reducing the consumption of solid fuels in the boiler house and the consumption of natural resources used by association will decrease. In addition, by abandoning boilers fired with solid fuels, mainly coal, the emission of carbon dioxide into the air will be limited. The potential of the values obtained is sufficiently detailed for the cooperative's roof potential, because they are data on the value of the possible energy produced, which does not take into account the limited efficiency planned for the use of solar technology. Using an installation consisting of the placement of photovoltaic panels on roofs in areas of the highest solar radiation intensity allows for maximizing the energy benefits of real estate. It has both economic and environmental benefits for residents. A reduced consumption of natural resources means limiting the use of the environment. This has a positive effect both on the environment and the inhabitants of this neighborhood. In addition, a reduction in stoves fired with minerals will reduce the emission of carbon dioxide to the atmosphere and finally reduce the vulnerability of socio-environmental systems.

Author Contributions: Conceptualization, A.B. and S.S.; methodology, A.B. and S.S.; software, A.B., M.Ś. and S.S.; validation, A.B., M.Ś. and S.S.; formal analysis, A.B. and S.S.; investigation, A.B. and S.S.; resources, S.S.; data curation, A.B., M.S. and S.S.; writing—original draft preparation, A.B. and J.K.K.; writing—review and editing, J.K.K.; visualization, A.B.; supervision, J.K.K. and S.S.

Funding: This research was funded by the Department of Spatial Economy of the Wrocław University of Environmental and Life Sciences from statutory funds.

Acknowledgments: The publication has been prepared as a part of the Support Programme of the Partnership between Higher Education and Science and Business Activity Sector financed by City of Wrocław.

Conflicts of Interest: The authors declare no conflict of interest.

\section{References}

1. Antolak, M. Wybrane Elementy Zarzadzania Ochrona Środowiska w Polsce; Mantis Olsztyn: Austin, Poland, 2013.

2. Rogall, H. The Economics of Sustainable Development; Springer-Verlag: New York, NY, USA, 2009; ISBN 9783895187650.

3. Szyszka, B. The Effectiveness of the Eco-Management and Audit Scheme EMAS in Organizations on Polish Territory. 2016. Poznań University of Economics and Business. Available online: http://www.wbc.poznan.pl/ Content/393452/Szyszka_Beata-rozprawa_doktorska.pdf (accessed on 5 July 2019).

4. Caekelbergh, A.F. Zintegrowane Zarzadzanie Środowiskiem. Systemowe Zależności Między Polityka, Prawem, Zarzadzaniem i Technika; Oficyna Wolters Kluwer Business: Alphen aan den Rijn, The Netherlands, 2013; ISBN 9788326438110.

5. Matthaios, S. Minimizing Energy Consumption, Energy Poverty and Global and Local Climate Change in the Built Environment: Innovating to Zero; Elsevier: Amsterdam, The Netherlands, 2018. 
6. Central Statistical Office; Production Department, Ministry of Energy. Energy Consumption in Households in 2015; Statistics Public Establishment: Warsaw, Poland, 2017. Available online: https://stat.gov.pl/download/gfx/portalinformacyjny/en/defaultaktualnosci/3304/3/8/1/energy_from_ renewable_sources_in_2015.pdf (accessed on 5 July 2019).

7. Żyromski, A.; Biniak-Pieróg, M.; Burszta-Adamiak, E.; Zamiar, Z. Evaluation of relationship between air pollutant concentration and meteorological elements in winter months. J. Water L. Dev. 2014, 22, 25-32. [CrossRef]

8. Kamińska, J.A. Probabilistic forecasting of nitrogen dioxide concentrations at an urban road intersection. Sustainability 2018, 10, 4213. [CrossRef]

9. Lobaccaro, G.; Croce, S.; Lindkvist, C.; Munari Probst, M.C.; Scognamiglio, A.; Dahlberg, J.; Lundgren, M.; Wall, M. A cross-country perspective on solar energy in urban planning: Lessons learned from international case studies. Renew. Sustain. Energy Rev. 2019, 108, 209-237. [CrossRef]

10. Gielen, D.; Boshell, F.; Saygin, D.; Bazilian, M.D.; Wagner, N.; Gorini, R. The role of renewable energy in the global energy transformation. Energy Strateg. Rev. 2019, 24, 38-50. [CrossRef]

11. European Commission. EU Actions to Improve Environmental Compliance and Governance; European Commission: Brussels, Belgium, 2018.

12. United Nations. Adoption of the Paris Agreement. In Proceedings of the Conference of the Parties on Its Twenty-First Session, Paris-Le Bourget, France, 30 November 2015.

13. Ministry of Economy. Energy Policy of Poland Until 2030. Energy Policy; 2009. Available online: https://www.iea.org/policiesandmeasures/pams/poland/name-24723-en.php (accessed on 5 July 2019).

14. European Commission. Europe 2020 Strategy; European Commission: Brussels, Belgium, 2010.

15. Transforming Our World: The 2030 Agenda for Sustainable Development. 2018. Available online: https://sustainabledevelopment.un.org/post2015/transformingourworld (accessed on 5 July 2019).

16. Bazan-Krzywoszańska, A.; Skiba, M.; Mrówczyńska, M.; Sztubecka, M.; Bazuń, D.; Kwiatkowski, M. Green energy in municipal planning documents. E3S Web Conf. 2018, 45, 00006. [CrossRef]

17. Poskrobko, B. Zarządzanieekologiczne w przedsiębiorstwiejakonarzędziewdrażaniaekorozwoju. In MechanizmyiUwarunkowaniaEkorozwoju; Publisher Białystok Politechnika Białostocka: Białostocka, Poland, 1996; ISBN 9788390556321.

18. Szewrański, S.; Świąder, M.; Kazak, J.K.; Tokarczyk-Dorociak, K.; van Hoof, J. Socio-Environmental Vulnerability Mapping for Environmental and Flood Resilience Assessment: The Case of Ageing and Poverty in the City of Wrocław, Poland. Integr. Environ. Assess. Manag. 2018. [CrossRef] [PubMed]

19. Marcyniuk-Kluska, A. Environmental management in the scope of economic sustainable development. Zeszyty Naukowe Uniwersytetu Przyrodniczego w Siedlcach 2013, 23, 129-140.

20. Wang, T.; Kazak, J.; Han, Q.; de Vries, B. A framework for path-dependent industrial land transition analysis using vector data. Eur. Plan. Stud. 2019, 27, 1391-1412. [CrossRef]

21. Huld, T. PVMAPS: Software tools and data for the estimation of solar radiation and photovoltaic module performance over large geographical areas. Sol. Energy 2017, 142, 171-181. [CrossRef]

22. Sarmiento, N.; Belmonte, S.; Dellicompagni, P.; Franco, J.; Escalante, K.; Sarmiento, J. A solar irradiation GIS as decision support tool for the Province of Salta, Argentina. Renew. Energy 2019, 132, 68-80. [CrossRef]

23. Harper, M.; Anderson, B.; James, P.; Bahaj, A. Assessing socially acceptable locations for onshore wind energy using a GIS-MCDA approach. Int. J. Low-Carbon Technol. 2019, 14, 160-169. [CrossRef]

24. Dominik, K.; Skotak, K. The conception of decision support system for assessment and management of ambient air quality. Inf. Syst. Manag. 2012, 1, 305-317.

25. Giordano, R.; Pilli-Sihvola, K.; Pluchinotta, I.; Matarrese, R.; Perrels, A. Urban adaptation to climate change: Climate services for supporting collaborative planning. Clim. Serv. 2019. [CrossRef]

26. Massei, G.; Rocchi, L.; Paolotti, L.; Greco, S.; Boggia, A. Decision Support Systems for environmental management: A case study on wastewater from agriculture. J. Environ. Manag. 2014, 146, 491-504. [CrossRef]

27. Dong, Y.; Miraglia, S.; Manzo, S.; Georgiadis, S.; Sørup, H.J.D.; Boriani, E.; Hald, T.; Thöns, S.; Hauschild, M.Z. Environmental sustainable decision making-The need and obstacles for integration of LCA into decision analysis. Environ. Sci. Policy 2018, 87, 33-44. [CrossRef]

28. Van Hoof, J.; Kazak, J.K. Urban ageing. Indoor BuiltEnviron. 2018, 27, 583-586. [CrossRef] 
29. Kazak, J.K.; van Hoof, J. Decision support systems for a sustainable management of the indoor and built environment. Indoor Built Environ. 2018, 27, 1303-1306. [CrossRef]

30. Pérez-Pérez, R.; Benito, B.M.; Bonet, F.J.; Modele, R. An environmental model repository as knowledge base for experts. Expert Syst. Appl. 2012, 39, 8396-8411. [CrossRef]

31. Chang, N.B.; Parvathinathan, G.; Breeden, J.B. Combining GIS with fuzzy multicriteria decision-making for landfill siting in a fast-growing urban region. J. Environ. Manag. 2008, 87, 139-153. [CrossRef]

32. Rahman, M.A.; Rusteberg, B.; Gogu, R.C.; Lobo Ferreira, J.P.; Sauter, M. A new spatial multi-criteria decision support tool for site selection for implementation of managed aquifer recharge. J. Environ. Manag. 2012, 99, 57-61. [CrossRef]

33. Van Hoof, J.; Bennetts, H.; Hansen, A.; Kazak, J.K.; Soebarto, V. The living environment and thermal behaviours of older south australians: A multi-focus group study. Int. J. Environ. Res. Public Health 2019, 16, 935. [CrossRef]

34. Przybyła, K.; Kulczyk-Dynowska, A.; Kachniarz, M. Quality of Life in the Regional Capitals of Poland. J. Econ. Issues 2014, 48, 181-196. [CrossRef]

35. Przybyłowicz, A. The legal position of persons dependent on long-term care in the Republic of Poland. In Long-Term Care in Europe; Springer: Cham, Switzerland, 2018; ISBN 9783319700816. Available online: https://link.springer.com/chapter/10.1007/978-3-319-70081-6_10 (accessed on 5 July 2019).

36. Bieda, A. Urban renewal and the value of real properties. Stud. Reg. I Lokal. 2017, 69, 5-28.

37. Trembecka, A.; Kwartnik-Pruc, A. An analysis of the changes in the structure of allotment gardens in poland and of the process of regulating legal status. Sustainability 2018, 10, 3829. [CrossRef]

38. Trojanek, R.; Gluszak, M.; Tanas, J. The Effect of Urban Green Spaces on House Prices in Warsaw. Int. J. Strateg. Prop. Manag. 2018, 22, 358-371. [CrossRef]

39. Jacksohn, A.; Grösche, P.; Rehdanz, K.; Schröder, C. Drivers of renewable technology adoption in the household sector. Energy Econ. 2019, 81, 216-226. [CrossRef]

40. Palicki, S.; Racka, I. Influence of Urban Renewal on the Assessment of Housing Market in the Context of Sustainable Socioeconomic City Development. In International Summit, Smart City $360^{\circ}$; Lecture Notes of the Institute for Computer Sciences, Social-Informatics and Telecommunications Engineering (LNICST); Springer: Cham, Switzerland, 2016; Available online: https://link.springer.com/chapter/10.1007/978-3-319-33681-7_76 (accessed on 5 July 2019).

41. Świtała, M.; Cichosz, M.; Trzessiok, J. How to Achieve Customer Satisfaction? Perspective of Logistics Outsourcing Performance. LogForum 2019, 15, 39-51. [CrossRef]

42. Szewrański, S.; Kazak, J.; Sylla, M.; Świąder, M. Spatial data analysis with the use of ArcGIS and Tableau systems. In Lecture Notes in Geoinformation and Cartography; Springer International Publishing: Cham, Switzerland, 2017; pp. 337-349. Available online: https://ink.springer.com/chapter/10.1007/978-3-319-451237_24 (accessed on 5 July 2019).

43. Wohlgemuth, N.; Wojtkowska-Łodej, G. Policies for the promotion of renewable energy in Poland. Appl. Energ 2003, 76, 111-121. [CrossRef]

44. Szewrański, S.; Bochenkiewicz, M.; Kachniarz, M.; Kazak, J.K.; Sylla, M. 2018 International Conference on New Energy and Future Energy System (NEFES 2018). Available online: https://iopscience.iop.org/article/10. 1088/1755-1315/188/1/011001 (accessed on 5 July 2019).

45. Kazak, J.K.; Świąder, M. SOLIS-A novel decision support tool for the assessment of solar radiation in ArcGIS. Energies 2018, 11, 2015. [CrossRef]

46. Klapa, P.; Mitka, B. Application of terrestrial laser scanning to the development and updating of the base map. Geod. Cartogr. 2017, 66, 59-71. [CrossRef]

47. Dabek, P.B.; Żmuda, R.; Szczepański, J.; Ćmielewski, B. Evaluation of water soil erosion processes in forest areas in the Western Sudetes using terrestrial laser scanning and GIS tools. E3S Web Conf. 2018, 44, 00026. [CrossRef]

48. Klapa, P.; Mitka, B.; Brożek, P. Inventory of Various Stages of Construction Using Tls Technology. In Proceedings of the 18th International Multidisciplinary Scientific GeoConference(SGEM2018), Informatics, Geoinformatics Remote Sensing, Albena, Bulgaria, 30 June-9 July 2018; Volume 18.

49. Centralny Ośrodek Dokumentacji Geodezyjneji Kartograficznej. Available online: http://www.codgik.gov.pl/ index.php/zasob/numeryczne-dane-wysokosciowe.html (accessed on 5 July 2019). 
50. Central Statistical Office. Available online: https://stat.gov.pl/download/gfx/portalinformacyjny/pl/ defaultaktualnosci/5485/1/6/1/energia_2018.pdf (accessed on 5 July 2019).

51. Hofierka, J.; Kaňuk, J. Assessment of photovoltaic potential in urban areas using open-source solar radiation tools. Renew. Energy 2009, 34, 2206-2214. [CrossRef]

52. Klapa, P.; Mitka, B.; Zygmunt, M. Study into Point Cloud Geometric Rigidity and Accuracy of TLS-Based Identification of Geometric Bodies. IOP Conf. Ser. Earth Environ. Sci. 2017, 95, 032008. [CrossRef]

53. Mitka, B.; Klapa, P.; Piech, I. Comparative analysis of geospatial data received by TLS and UAV technologies for the quarry. In Proceedings of the 18th International Multidisciplinary Scientific GeoConference (SGEM2018), Informatics, Geoinformatics and Remote Sensing, Albena, Bulgaria, 30 June-9 July 2018.

54. Kaynak, S.; Kaynak, B.; Özmen, A. A software tool development study for solar energy potential analysis. Energy Build. 2018, 162, 134-143. [CrossRef]

55. Holmgren, J.; Persson, Å.; Söderman, U. Species identification of individual trees by combining high resolution LiDAR data with multi-spectral images. Int. J. Remote Sens. 2008, 29, 1537-1552. [CrossRef]

56. Agugiaro, G.; Remondino, F.; Stevanato, G.; De Filippi, R.; Furlanello, C. Estimation of solar radiation on building roofs in mountainous areas. ISPRS-Int. Arch. Photogramm. Remote Sens. Spat. Inf. Sci. 2013, 38, 155-160. [CrossRef]

57. Mainzer, K.; Fath, K.; Mckenna, R.; Stengel, J.; Fichtner, W.; Schultmann, F. A high-resolution determination of the technical potential for residential-roof-mounted photovoltaic systems in Germany. Sol. Energy 2014, 105, 715-731. [CrossRef]

58. Redweik, P.M.; Catita, C.; Brito, M.C. 3D local scale solar radiation model based on urban LiDAR data. Int. Arch. Photogramm. Remote Sens. Spatial Inf. Sci. 2011, XXXVIII-4/W19, 265-269. Available online: https://doi.org/10.5194/isprsarchives-XXXVIII-4-W19-265-2011 (accessed on 5 July 2019).

59. Wijeratne, W.M.P.U.; Yang, R.J.; Too, E.; Wakefield, R. Design and development of distributed solar PV systems: Do the current tools work? Sustain. Cities Soc. 2019, 45, 553-578. [CrossRef]

60. Jakica, N. State-of-the-art review of solar design tools and methods for assessing daylighting and solar potential for building-integrated photovoltaics. Renew. Sustain. Energy Rev. 2018, 81, 1296-1328. [CrossRef]

61. Shen, J.; Cheng, C. A Generalized Decision Support System for Short-Term Scheduling of China's Big Hydropower Systems. In World Environmental and Water Resources Congress 2015; American Society of Civil Engineers: Reston, VA, USA; pp. 1872-1886. Available online: https://ascelibrary.org/doi/abs/10.1061/ 9780784479162.183?src=recsys (accessed on 5 July 2019).

62. Kurtyka-Marcak, I.; Hełdak, M.; Przybyła, K. The Actual Demand for the Elimination of Architectural Barriers among Senior Citizens in Poland. Int. J. Environ. Res. Public Health 2019, 16, 2601.

63. Dąbrowska, J.; Pawęska, K.; Dąbek, P.; Stodolak, R. The Implications of Economic Development, Climate Change and European Water Policy On Surface Water Quality Threats. Acta Sci. Pol. Formatio Circumiectus 2017, 16, 111-123.

64. Chintala, V.; Subramanian, K.A. A comprehensive review on utilization of hydrogen in a compression ignition engine under dual fuel mode. Renew. Sustain. Energy Rev. 2017, 70, 472-491. [CrossRef]

(C) 2019 by the authors. Licensee MDPI, Basel, Switzerland. This article is an open access article distributed under the terms and conditions of the Creative Commons Attribution (CC BY) license (http://creativecommons.org/licenses/by/4.0/). 